УДК 616.89:316.363.5

Для цитирования: Костарев В.В. Психологические предикторы нарушений психического здоровья у супругов в ситуации развода. Сибирский вестник психиатрии и наркологии. 2017; 3 (96): 64-70. https://doi.org/10.26617/1810-3111-2017-3(96)-6470

\title{
Психологические предикторы нарушений психического здоровья у супругов в ситуации развода
}

\section{Костарев В.В.}

Филиал Московского психолого-социального университета в г. Красноярске 660012, Красноярск, ул. Качинская, 64/9

\section{PEЗЮME}

Цель: выявление психологических предикторов нарушения психического здоровья супругов в ситуации развода. Материалы: в выборку исследования, сформированную случайным способом, вошло 125 женщин (средний возраст 29 $\pm 5,14$ года) и 130 мужчин (35+3,74 года), подавших заявление о расторжении брака. 1-я группа - мотивация брака по расчету, 2-я группа - по любви. Методы: Многосторонний метод исследования личности, Томский опросник ригидности, Опросник невротических расстройств, Опросник социально-ролевой адекватности, Опросник ролевых ожиданий и притязаний в браке, Опросник самоорганизации деятельности и метод математической статистики. Результаты исследования свидетельствуют о несбывшихся социально-ролевых ожиданиях, снижении социально-ролевого функционирования, усилении невротических и психосоматических проявлений и психической ригидности, значимых различиях в самоорганизации деятельности. Заключение. Психологические предикторы (нарушения мультимодального психического состояния, усиление психической ригидности, субъективная оценка психического и психосоматического здоровья, искажение социально-ролевого функционирования, неудовлетворенные ожидания от брака, недостаточность самоорганизации) определяют кризисное переживание супругами развода и являются фактором риска нарушения психического здоровья. Установлены статистически значимые различия в представлениях супругов о нарушении здоровья. У женщин больше выражен уровень невротических проявлений, у мужчин - психосоматических. Высокий уровень невротической триады выявлен у супругов обоего пола с мотивацией брака по любви. Увеличение значений шкал актуальной, сенситивной и установочной ригидности у супругов всей выборки является фактором риска, усиления кризисного переживания и способствует нарушениям психического здоровья.

Ключевые слова: алкогольная зависимость, анозогнозия, женский алкоголизм, мишени персонализированной терапии, оценка эффективности терапии.

\section{ВВЕДЕНИЕ}

Обращение к изучению психологических факторов, определяющих психическое здоровье членов семьи, связано с тем, что именно нервнопсихические и психосоматические заболевания занимают одно из ведущих мест при возникновении семейных кризисов $[6,12,16,23]$. Ситуация развода, рассматриваемая в рамках клинической психологии в качестве ненормативного семейного кризиса, во многих случаях является психотравмирующей и тяжело переживается людьми, связанными родственными узами [10, 15,18, 21, 22].

Под разводом понимается разрыв супружеских отношений в его юридическом, экономическом и психологическом аспектах. Кризисный характер данного события обусловлен продолжительностью и болезненностью переживаний членов семьи и его дестабилизирующим влиянием на всю семейную систему [5, 17, $18,21]$. Критериями семейного кризиса являются: событие, вызывающее стресс, негативные переживания, связанные с этим событием, разрушение привычного уклада жизни, неопределенность будущего, нарушения психического здоровья членов семьи [1].

Анализ литературных источников по проблеме психического здоровья членов семьи свидетельствует о значительном числе исследований, посвященных психическому и психосоматическому здоровью детей. Показано, что у детей с хроническими заболеваниями психотравмирующими являлись семейные факторы, включая конфликты между членами семьи, развод родителей, проживание в неполной семье [7, 8, 13, 21].

Детские переживания развода родителей могут проявляться умеренной депрессией, апатией, негативизмом. Травматичность развода обусловлена ещё и тем, что кризисная ситуация в семье не является выбором ребенка. Распад семьи связан с крушением мира и может вызвать широкий спектр протестных, фобических, депрессивных реакций [7, 12, 13, 18. 19, 20]. В отечественной литературе при рассмотрении психических нарушений у членов семьи особое внимание уделяется наличию вредных привычек, склонности к аддиктивным нарушениям, формированию зависимых и созависимых расстройств у супругов [2, 3, 4].

Исследователи отмечают, что развод негативно сказывается на дальнейшей судьбе и здоровье зависимого от алкоголя человека [14].

Следует отметить, что в широком спектре нарушений психического здоровья членов семьи в ситуации развода не представлены данные о супругах, чье здоровье до возникновения критической ситуации не было нарушенным. Недостаточно психологической информации о гендерной специфике нарушений психического здоровья, о возможностях выполнения супругами ролевых обязанностей.

Цель исследования - выявление психологических предикторов нарушения психического здоровья супругов в ситуации развода.

\section{МАТЕРИАЛЫ И МЕТОДЫ}

С учетом того, что проявления кризиса на личностном уровне включают не только негативные последствия, но и потенциальные возможности его пре- 
одоления, становится необходимым системное выявление психологических факторов, нарушающих психическое здоровье, а также ресурсных составляющих преодоления кризисной ситуации. Исследовательская модель изучения кризисной насыщенности переживания супругами ситуации развода, которая способствует нарушению психического здоровья, представляет совокупность психологических предикторов, включающих мультимодальность психического состояния, психическую ригидность, особенности социально-ролевого функционирования, ожидания от супружества, субъективную оценку состояния психического и психосоматического здоровья.

Психологическим фактором, определяющим возможности совладания с кризисной ситуацией, а в конечном счете способствующим улучшению психического здоровья, выступает компонент личностного потенциала - способность к самоорганизации. Каждая составляющая кризисной насыщенности рассматривается с учетом гендерной принадлежности супругов и мотивации заключения брака.

Разработанный подход к анализу психического состояния и психического здоровья супругов в ситуации ненормативного семейного кризиса позволяет интегрировать теоретические положения кризисной психологии и психологии семьи, на стыке которых развивается новое направление в клинической психологии - психология семейных кризисов.

Выборка исследования формировалась случайным способом при наличии информированного согласия каждого участника исследования в территориальных отделах ЗАГСов, а также в медицинском центре «Клиника современных коррекционных и развивающих технологий» г. Красноярска. Всего обследовано 255 человек (125 женщин и 130 мужчин), подавших заявление о расторжении брака. Средний возраст

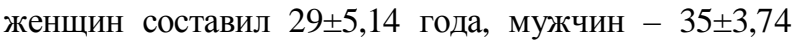
года. В исследовании приняли участие две группы испытуемых. Критерием отбора в группу являлась мотивация брака: по расчету (1-я группа) или по любви (2-я группа). Случаи смешанной мотивации исключались из исследования. 1-ю группу составили супруги обоего пола, вступившие в брачные отношения по расчету (материальное положение, социальный статус). Количество лиц в этой группе - 70 человек (35 мужчин и 35 женщин), время совместного

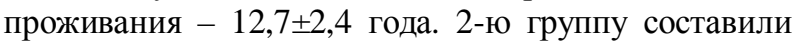
185 человек (93 мужчины, 92 женщины), время совместного проживания в браке $-9,6 \pm 1,7$ года.

Для решения поставленных задач использован ряд методик 1) «Многосторонний метод исследования личности» (ММИЛ, Березин Ф.Б., 2011); 2) «Томский опросник ригидности» (Залевский Г.В., 2000); 3) «Опросник невротических расстройств» (Вассерман Л.И. и др., 2003); 4) «Социально-ролевая адекватность» (Торохтий В.С., 2006); 5) «Ролевые ожидания и притязания в браке» (Волкова А.Н., 1979); 6) «Опросник самоорганизация деятельности» (Леонтьев Д.А., Мандрикова Е.Ю., Осин Е.Н., Плотникова А.В., Рассказова Е.И., 2007) [11]. В качестве методов мате- матической статистики применялся пакет программ STATISTICA, версия 6.0 для Windows.

Для экспериментальной проверки гипотезы о проявлениях психического здоровья супругов в ситуации развода в исследование включена 3-я (сравнительная) группа - пациенты с невротическими расстройствами, соответствующими по МКБ-10 рубрике F40-F49 (неврастения - F48.0), из них 41 мужчина и 54 женщины (средний возраст - 43,7 11,7 года.

\section{РЕЗУЛЬТАТЫ И ОБСУЖДЕНИЕ}

С помощью опросника «Социально-ролевые ожидания и притязания в браке» выявлено наличие неудовлетворенных потребностей и несбывшихся ожиданий от брака, которые вызывали эмоциональную напряженность, формировали кризисную насыщенность в семейной ситуации и создавали почву для возникновения ненормативного кризиса у супругов обоего пола.

Ведущими факторами развода для женщин являлись негативные эмоциональные переживания, неудовлетворенность выполнением родительских обязанностей мужем, отсутствие личностной общности с супругом, психологическая несовместимость, монотонность и однообразие семейной жизни. Среди несбывшихся ожиданий у женщин выявлено отсутствие моральной поддержки со стороны мужей, недостаточность помощи в воспитании детей и в хозяйственно-бытовой сфере.

Основными причинами развода для мужчин стали психологическая несовместимость, стремление к власти супруги, утрата интереса к ней. Ведущее место среди несбывшихся ожиданий заняло отсутствие личной общности с супругой, отсутствие моральной поддержки, несбывшиеся ожидания в плане внешней привлекательности супруги, несбывшиеся ожидания в сексуальной сфере.

Таким образом, несбывшиеся социально-ролевые ожидания и притязания в браке, недостаточность эмоциональной поддержки становятся ведущими неудовлетворенными потребностями у супругов обоего пола. Блокада значимых потребностей порождает семейный кризис, обусловливающий кризисную насыщенность переживания ситуации развода, и способствует нарушениям психического здоровья.

Дальнейший этап исследования определялся изучением специфики выполнения социальноролевых функций у супругов в ситуации развода с учетом половой принадлежности. Изучение данных проявлений осуществлялось с помощью опросника «Социально-ролевой адекватности супругов».

Анализ результатов свидетельствует о том, что у супругов женского пола, находящихся в состоянии расторжения брака, коэффициент ролевой адекватности равен 0,5 и ниже (максимальное значение 1). Это отражает наличие низкого уровня выполнения семейных ролей жены, матери, хозяйки - менее чем наполовину. Супруги находились за нижней границей исполнения ролевых ожиданий. Другая группа женщин осуществляла социально-ролевое функцио- 
нирование в пределах нижней границы. Только в $10,7 \pm 2,14 \%$ случаев супруги выполняли свои роли более чем наполовину.

Изучение ролевой адекватности супругов мужского пола показало, что в $4,35 \pm 0,71 \%$ случаев их коэффициент ролевой адекватности приближался к 1. Это свидетельствует о том, что в содержательном плане социально-ролевая адекватность проявлялась в виде способности самостоятельно действовать и разумно выполнять функциональные обязанности. Высокий уровень ролевой адекватности выявлен у $8,71 \pm 1,16 \%$ мужчин, у $21,69 \pm 7,41 \%$ - средний уровень, низкий уровень - у $30,51 \pm 8,4 \%$. Коэффициент ролевой адекватности, равный 0,5 , обнаружен у $34,8 \pm 9,22 \%$ мужчин, выполнявших свои роли мужа, отца, хозяина менее чем наполовину.

Таким образом, установлены низкие показатели ролевого функционирования у супругов женского пола по сравнению с супругами мужского пола (коэффициент ролевой адекватности у женщин 0,5, у мужчин в большинстве случаев данный показатель превышает эти значения ( $\mathrm{p}<0,01)$.

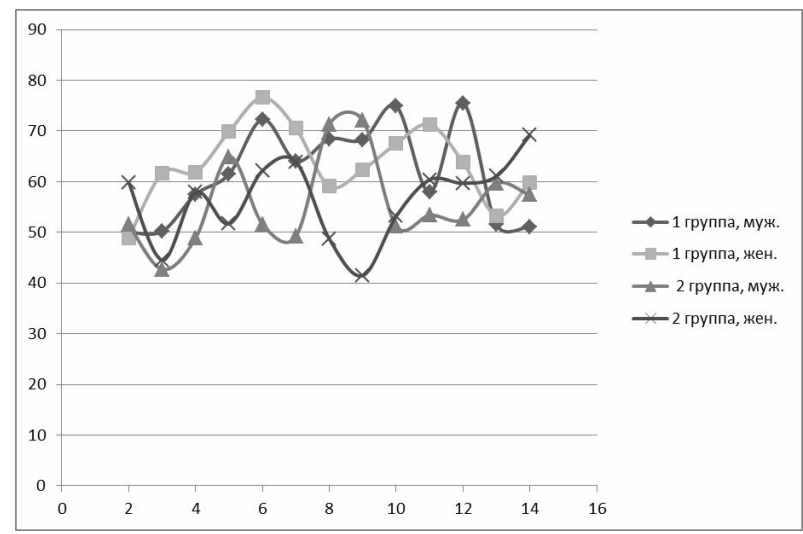

Рисунок 1. Особенности мультимодального психического состояния у супругов в ситуации развода

На рисунке 1 представлены психологические особенности мультимодального состояния у супругов обеих групп, выявленные с помощью ММИЛ. У супругов, вступивших в брак по любви, отмечается усиление ригидности, замкнутости, снижение стрессоустойчивости, нарастание сенситивных и ипохондрических проявлений. В условиях кризисной насыщенности ситуации для них характерны противоречия, когда стремление к достижению сочетается с избеганием неуспеха, а направленность на активную жизнедеятельность сочетается со склонностью к её блокированию. Кроме того, личностные особенности супругов, проявляющиеся в стремлении к доминированию, повышенном чувстве собственного достоинства, в ситуации стресса сочетаются с неуверенностью, снижением самооценки. При этом происходит усиление внутренней напряженности, так как блокируется возможность адекватного отреагирования переживания. Отмеченные выше психологические характеристики со- провождаются снижением поисковой активности, усилением тревоги, фиксации на негативных переживаниях, снижением продуктивности.

У супругов женского пола во 2-й группе по сравнению с мужчинами отмечается преобладание показателей по шкалам $\mathrm{F}(\mathrm{p}<0,01)$, «Невротический «сверхконтроль» поведения» $(\mathrm{p}<0,05)$, «Эмоциональная лабильность» $(\mathrm{p}<0,05)$, «Тревожность» $(\mathrm{p}<0,01)$, «Социальная интроверсия» $(\mathrm{p}<0,05)$. Это свидетельствует о большей выраженности внутренней напряженности, эмоциональной неустойчивости, повышенной склонности к аффективно насыщенным переживаниям. Важными характеристиками в плане развития нарушений психического состояния у супругов 2-й группы явились несдержанное, плохо контролируемое поведение, раздражительность, вспыльчивость, совершение необдуманных поступков, невысокая стрессоустойчивость.

Следует отметить, что усредненные показатели, полученные с помощью ММИЛ у супругов 1-й группы, также свидетельствуют о проявлениях невротизации. По сравнению с супругами 2-й группы эти показатели имеют более низкие значения $(\mathrm{p}<0,01)$.

Полученные данные позволяют сделать вывод о наличии нарушенных психических состояний у супругов, обусловленных переживанием кризисной ситуации развода. Выраженность и длительность этих состояний становится фактором риска нарушений психического здоровья. Показатели психического состояния с высокими уровнями эмоциональной напряженности, избыточной тревоги в большей степени характерны для супругов с мотивацией брака по любви в отличие от супругов с мотивацией брака по расчету ( $<<0,01)$.

Результаты, полученные с помощью ММИЛ, подтверждаются показателями методики ОНР. Так, у супругов 2-й группы установлены высокие значения по шкалам «Неуверенность в себе» (61,2 Тб), «Аффективная неустойчивость» $(69,4$ Тб), «Социальная неадаптивность» $(58,9$ Тб), «Познавательная и социальная пассивность» $(64,1$ Тб) «Невротический сверхконтроль поведения» (67,8 Тб).

Усредненные показатели всей выборки свидетельствуют о повышении по сравнению с нормой шкал «Колебания интенсивности жалоб», «Расстройства в сфере пищеварения», «Расстройства сердечно-сосудистой деятельности», «Психическая истощаемость», «Немотивированный страх», «Фобические расстройства».

Сравнительный анализ данных опросника ОНР свидетельствует о близости определенных параметров у супругов, находящихся в ситуации развода, и больных невротическими расстройствами. Установлены близкие показатели по шкалам «Аффективная неустойчивость», «Неуверенность в себе», «Познавательная и социальная пассивность», «Невротический «сверхконтроль». В 18,8 \% случаев всей выборки профили опросников ММИЛ и ОНР имели сходные значения у супругов и пациентов с 
невротическими расстройствами (различия статистически не значимы).

Наличие сходных проявлений, свидетельствующих о нарушениях психического и психосоматического здоровья у пациентов и супругов в ситуации развода, ещё раз подтверждает необходимость дифференцированного подхода.

Сравнение показателей преморбидной ригидности (ПМР) между обеими группами показало, что наиболее высокие значения отмечаются у супругов 1-й группы $(\mathrm{p}<0,01)$. Во 2-й группе показатели шкалы преморбидной ригидности были умеренно повышены в $69,5 \pm 4,18 \%$ случаев.

Наличие выраженной ригидности у супругов может свидетельствовать о трудностях в ситуациях, требовавших каких-либо перемен в жизни, нового подхода в реализации планов, принятия собственных решений. Высокие показатели шкалы ПМР подтверждают низкие возможности в разрешении сложных жизненных ситуаций в предыдущие периоды жизни. Постоянное эмоциональное напряжение с фиксацией на данных проявлениях, выраженный дискомфорт в стрессовых ситуациях, трудности осознания мотивов своего поведения способствуют утяжелению психического состояния.

Рост показателей по шкалам актуальной ригидности, сенситивной ригидности, установочной ригидности у супругов в ситуации развода может рассматриваться как фактор риска, усиливающий кризисную насыщенность переживания и приводящий к нарушениям психического здоровья. Можно утверждать, что проявления психической ригидности являются психологической детерминантой, играющей важную роль в формировании кризисной насыщенности переживания супругами ситуации развода.

Анализ корреляционных взаимосвязей в 1-й группе позволил выявить прямую взаимосвязь параметров шкал «Преморбидная ригидность» со шкалами опросника ОНР: шкалой 14 «Фобические расстройства» $(\mathrm{r}=0,45, \mathrm{p}<0,01)$ и шкалой 22 «Социальная неадаптивность» $(\mathrm{r}=0,46, \mathrm{p}<0,01)$; шкалой 6 ММИЛ «Аффективная ригидность» ( $\mathrm{r}=0,588$, $\mathrm{p}<0,01)$ и обратную зависимость со шкалой 2 опросника ОНР «Колебания интенсивности жалоб» (r=0,46, p<0,01). Связь параметров «Преморбидная ригидность» с фобическими расстройствами указывает, что на предшествующих этапах онтогенеза супруги испытывали разные страхи. Вероятно, с возрастом эта практика закрепилась и выкристаллизовалась в социальную дистанцированность, потребность в одиночестве, дискомфорт в ситуациях социального взаимодействия, а также в повышенную тревожность, неуверенность, всевозможные страхи.

Анализ результатов дисперсионного анализа выявил увеличение показателей по шкале опросника ОНР «Познавательная и социальная пассивность» в группе супругов, заключивших брак по любви, относительно этих параметров в группе лиц, вступивших в брак по расчету. Особенно ярко эти раз- личия проявились в группе женщин. Испытуемые, заключившие брак по любви, отличались низкой интеллектуальной продуктивностью, замедлением ассоциативных процессов, ограничением круга общения, недифференцированным характером интересов, недостаточной общительностью, затруднениями в установлении контактов, отсутствием потребности в межличностных связях. Эти особенности были более выраженными в группе женщин.

Для решения задач исследования, направленных не только на выявление психологических детерминант кризисной насыщенности переживания ситуации развода супругами с учетом половой принадлежности и мотивов вступления в брак, но и на выявление компонентов личностного потенциала в кризисной ситуации, проводилось изучение одного из них с помощью «Опросника самоорганизации деятельности» (Мадрикова Е.Ю., 2012).

Проведенное исследование показало, что у супругов, вступивших в брак по любви, относительно вступивших в брак по расчету, показатели шкалы «Планомерность» отражают низкие значения этих параметров $(\mathrm{p}<0,05)$. Это свидетельствует о том, что у супругов 2-й группы навыки планирования своей жизни развиты слабо, планы подвержены частой смене, отсутствуют устойчивость и долговременность планирования, отмечаются недостаточная прогнозируемость и частая смена установок. При этом поставленная цель редко бывает достигнута, планирование оказывается недейственным, нереалистичным. Супруги предпочитают не задумываться о своём будущем, цели выдвигают под влиянием окружения и случайных обстоятельств.

Супруги, вступившие в брак по расчету, имели высокие показатели по шкале «Планомерность», что указывало на сформированные потребности, осознанное планирование деятельности, самостоятельное выдвижение целей и их осуществление.

Параметры шкалы 2 «Целеустремленность», указывающие на направленность и концентрацию в достижении определенной цели, у супругов 2-й

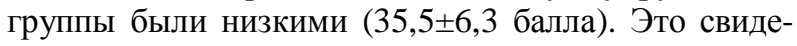
тельствует о невысокой целеустремленности, желании «плыть по течению». При этом супруги 1-й группы имели достоверно более высокие баллы по шкале «Целеустремленность» относительно супругов 2-й группы $(\mathrm{p}<0,05)$, что свидетельствовало о стремлении к достижению поставленных задач, несмотря ни на какие трудности, подчиняя решению этих задач все свои мысли, чувства и действия.

Результаты исследования по шкале «Настойчивость», измеряющей склонность личности к приложению волевых усилий для завершения начатого дела и упорядочения активности, у супругов 2-й группы также выявили низкие значения $(21,4 \pm 7,5$ балла). Полученные по этой шкале результаты характеризовали супругов, вступивших в брак по любви, как личностей, не способных к длительным волевым усилиям для доведения начатого дела до конца, часто отвлекающихся на посторонние дела. 
Они не были способны преодолевать препятствия, а при столкновении с трудностями, особенно неожиданными, часто вообще отказывались от цели.

У супругов 1-й группы по шкале «Настойчивость» на уровне достоверности выявлены более высокие баллы относительно лиц, вступивших в брак по любви $(\mathrm{p}<0,05)$. Это характеризовало супругов, вступивших в брак по расчету, как более волевых и организованных, способных структурировать поведенческую активность и завершать начатое дело, несмотря на возникающие трудности. Установленные показатели самоорганизации являются невысокими у супругов 2-й группы по сравнению с супругами 1-й группы.

Т а б л и ц а 1 Психологические характеристики личностного потенциала у супругов по опроснику «Самоорганизация деятельности»

\begin{tabular}{|l|c|c|}
\hline \multicolumn{1}{|c|}{ Диагностический показатель } & 1 -я группа & 2 -я группа \\
\hline Шкала планомерности & $27,2 \pm 4,3$ & $18,9 \pm 3,6^{*}$ \\
\hline Шкала наличия целей & $41,8 \pm 3,2$ & $35,5 \pm 6,3^{*}$ \\
\hline Шкала настойчивости & $33,9 \pm 2,5$ & $21,4 \pm 7,5^{* *}$ \\
\hline Шкала фиксации & $18,2 \pm 1,5$ & $27,8 \pm 9,4^{* *}$ \\
\hline Шкала самоорганизации & $17,6 \pm 1,23$ & $7,7 \pm 1,3 * *$ \\
\hline Шкала ориентации на настоящее & $14,9 \pm 0,6$ & $10,8 \pm 1,4$ \\
\hline
\end{tabular}

Пр и м еч ан и е. Достоверность различий исходных величин дана по группам сравнения: $*-\mathrm{p}<0,05 ; * *-\mathrm{p}<0,01$.

Таким образом, установлены особенности компоненты личностного потенциала, свидетельствующей о различиях совладания с кризисной ситуацией у супругов с учетом половых различий и мотивации вступления в брак. Новая психологическая информация позволяет индивидуализировать психологическую работу с парами, переживающими ситуацию развода.

\section{ЗАКЛЮЧЕНИЕ}

Совокупность психологических предикторов (нарушения мультимодального психического состояния, усиление проявлений психической ригидности, субъективная оценка психического и психосоматического здоровья, искажение социально-ролевого функционирования, неудовлетворенные ожидания от брака, недостаточность самоорганизации) определяет кризисную насыщенность переживания супругами ситуации развода и является фактором риска нарушения психического здоровья. Установлены статистически значимые различия в представлениях супругов о нарушении здоровья с учетом половой принадлежности и мотивации брака. У супругов женского пола в большей степени выражен уровень невротических проявлений, у мужчин - психосоматических. Высокий уровень невротической триады выявлен у супругов обоего пола с мотивацией брака по любви. Увеличение значений шкал актуальной ригидности, сенситивной и установочной ригидности у супругов всей выборки является фактором риска усиления кризисной насыщенности переживания, способствующим нарушениям психического здоровья.

Проведенное исследование свидетельствует о необходимости дифференцированного подхода при осуществлении психологической помощи супругам в ситуации развода.

\section{КОНФЛИКТ ИНТЕРЕСОВ}

Автор заявляет об отсутствии конфликта интересов в связи с публикацией данной статьи.

\section{ИСТОЧНИК ФИНАНСИРОВАНИЯ}

Автор заявляет об отсутствии финансирования при проведении исследования.

\section{СООТВЕТСТВИЕ ПРИНЦИПАМ ЭТИКИ}

Работа соответствует этическим стандартам, разработанным согласно Хельсинской декларации ВМА (протокол заседания этического комитета при Филиале Московского психолого-социального университета в г. Красноярске № 83 от 21.05.2014 г.).

\section{ЛИТЕРАТУРА}

1. Агадзе Н.В. Психосоциальное благополучие и психическое здоровье в чрезвычайных и кризисных ситуациях. Оказание психологической и психиатрической помощи при чрезвычайных ситуациях: учебное пособие / под ред. А.М. Чакиева. Бишкек, 2013: 114-133.

2. Айвазова Д.Г. Методические возможности исследования удовлетворенности брачными отношениями. Сибирский психологический журнал. 2014; 51: 148-156.

3. Бохан Н.А., Стоянова И.Я., Мазурова Л.В. Психология зависимости и созависимости у женщин из аддиктивных семей. Издательство «Иван Федоров». Томск, 2011: 120.

4. Будакова А.В., Сметанова Ю.В., Богомаз С.А. Психологическая безопасность как условие развития личностного потенциала. Вестник ТГУ. 2010; 338: 156-159.

5. Василюк Ф.Е. Психология переживания. М., 1984.

6. Гуткевич Е.В. Современная семья в аспекте психологии здоровья личности: проблемы развития и возможности превенции. Сибирский психологический журнал. 2014; 51: 120-132.

7. Дрождина Е.Н., Ковалевская О.Б., Серавина О.Ф. и др. Роль психотравмирующих факторов в дезадаптации детей и подростков, страдающим ювенильным артритом. Социальная $u$ клиническая психиатрия. 2012; 22 (1): 44-46.

8. Игумнов С.А. Психическое развитие детей в норме и патологии. СПб.: Питер, 2004: 480.

9. Кулаков С.А. Основы психосоматики. СПб.: Речь, 2003: 287.

10. Куфтяк Е.В. Совладание и психологические защиты супругов в период динамических кризисов: Семейная устойчивость как психологический феномен. [Электронный ресурс]. Медицинская психология в России. 2014; 1 (24): 11 URL: http://mprj.ru

11. Леонтьев Д.А., Мандрикова Е.Ю., Осин Е.Н., Плотникова А.В., Рассказова Е.И. Опыт структурной диагностики личностного потенциала. Психологическая диагностика. М., Обнинск, 2007; 1: 8-31.

12. Лифинцева А.А., Холмогорова А.Б. Семейные факторы психосоматических расстройств у детей и подростков. Консультативная психология и психотерапия. 2015; 23 (1): 70-83.

13. Мазурова Н.В. Семья и болезнь ребёнка: вопросы психологической адаптации. Личность, семья и общество: вопросы педагогики и психологии: материалы XXXI международной заочной научно-практической конференции. Новосибирск:, 2013: 110-120.

14. Меринов А.В., Сомкина О.Ю. Влияние развода на суицидологические и личностно-психологические характеристики мужчин, страдающих алкогольной зависимостью. [Электронный ресурс]. Медицинская психология в России. 2013; 2 (19).

15. Никольская И.М. Клиническая психология семьи: основные положения. [Электронный ресурс]. Медицинская психология в России. 2010; 4 URL: http://medpsy.ru

16. Никольская И.М. Психологическая защита и копингповедение в экстремальных и чрезвычайных ситуациях. Оказание психологической и психиатрической помощи при чрезвычайных ситуациях: учебное пособие / под ред. А.М. Чакиева. Бишкек, 2013: 33-40.

17. Новикова Е.В. О некоторых характеристиках общения между супругами. Вопросы психологии. 2009; 4: 15-19.

18. Олифирович Н.И.., Зинкевич-Куземкина Т.А, Велента Т.Ф. Психология семейных кризисов. СПб.: Речь, 2006: 360.

19. Холмогорова А.Б., Воликова С.В. Семейный контекст рас- 
стройств аффективного спектра. Социальная и клиническая психиатрия. 2004; 2: 11-20.

20. Холмогорова А.Б., Гаранян Н.Г., Шайб П., Виршинг М. Эмоции и психическое здоровье в социальном и семейном контексте (на модели соматоформных расстройств). [Электронный ресурс]. Медицинская психология в России. 2011; 1. URL: http:// medpsy.ru

21. Эйдемиллер Э.Г., Никольская И.М., Добряков И.В. Семейная психотерапия и клиническая психология семьи: традиции и современное состояние. [Электронный ресурс]. Меди- цииская психология в России. 2014; 6 (29). URL: http://mprj.ru 22. Duggan C., Sham P., Burleson, M.H., Trevathan, W.R., Todd M.P. Family history as a predictor of poor long - term outcome in depression. British Journal of Psychiatry. 2000; 157: 185-191.

23. Lecic-Tosevski D., Vukovic O., Stepanovic J. Stress and personality. Psychiatrike. 2011; Oct.-Dec; 22 (4): 290-297.

Поступила в редакцию 20.04.2017 Утверждена к печати 26.06.2017

Костарев Владислав Владимирович, преподаватель кафедры психологии и логопедии.

Костарев Владислав Владимирович, vladkost@list.ru

УДК 616.89:316.363.5

For citation: Kostarev V.V. Psychological predictors of mental health problems in spouses in the situation of divorce. Siberian Herald of Psychiatry and Addiction Psychiatry. 2017; 3 (96): 64-70. https://doi.org/10.26617/1810-3111-2017-3(96)-64-70

\section{Psychological predictors of mental health problems in spouses in the situation of divorce}

\section{Kostarev V.V.}

Branch of Moscow Psychological-Social University in Krasnoyarsk Kachinskaya Street 64/9, 660012, Krasnoyarsk, Russian Federation

\section{ABSTRACT}

Objective: to reveal psychological predictors of mental health problems in spouses in the situation of divorce. Materials: study sample included (by random method) 125 women (mean age $29 \pm 5.14$ years) and 130 men (35 \pm 3.74 years) who filed for a divorce: group 1 - motivation of marriage of convenience, group 2 - motivation of love match. Methods: MMPI, Tomsk Rigidity Questionnaire by Zalevsky, Neurotic Disorders Questionnaire, Social-Role Adequacy Questionnaire, Role Expectations and Claims in the Marriage Questionnaire, Self-Organizing Activity Questionnaire and method of mathematical statistics. Results: The results of the study testified to not realized social- role expectations, reduction in the social- role functioning, strengthening neurotic and psychosomatic manifestations and mental rigidity, significant differences in self-organizing activity. Conclusion. Psychological predictors (disturbances of multimodal mental state, strengthening mental rigidity, subjective evaluation of mental and psychosomatic health, distortion of social- role functioning, dissatisfied expectations from the marriage, insufficiency of selforganisation) determined crisis experience of divorce by spouses and were a risk factor for mental health problems. Statistically significant differences in the ideas of spouses about health problems were identified. The level of neurotic manifestations was higher in women, of psychosomatic ones - in men. A high level of neurotic triad was revealed in souses of both sexes with motivation of love match. An increase in the values of the scales of relevant, sensitive and attitudinal rigidity in spouses of the total sample was a risk factor for strengthening crisis experience and contributed to mental health problems.

\section{Keywords: alcohol dependence, anosognosia, female alcoholism, personalized therapy targets, therapy efficiency evaluation.}

\section{REFERENCES}

1. Agadze N.V. Psihosotsialnoe blagopoluchie i psihicheskoe zdorove $\mathrm{v}$ chrezvyichaynyih i krizisnyih situatsiyah. Okazanie psihologicheskoy i psihiatricheskoy pomoschi pri chrezvyichaynyih situatsiyah: uchebnoe Posobie [Psychosocial wellbeing and mental health in emergency situations. Psychological and psychiatric aid rendering in emergency situations: tutorial]. A.M. Chakiev, ed. Bishkek, 2013: 114-133 (in Russian).

2. Ayvazova D.G. Metodicheskie vozmozhnosti issledovaniya udovletvorennosti brachnyimi otnosheniyami [Methodical approaches of researching the satisfaction level in marital relationships]. Sibirskiy psihologicheskiy zhurnal - Siberian Psychological Journal. 2014; 51: 148-156 (in Russian).

3. Bokhan N.A., Stoyanova I.Ya., Mazurova L.V. Psihologiya zavisimosti i sozavisimosti u zhenschin iz addiktivnyih semey [Psychology of dependence and co-dependence in women from addictive families]. Tomsk: Publishing House "Ivan Fedorov". Tomsk, 2011: 120 (in Russian).

4. Budakova A.V., Smetanova Yu.V., Bogomaz S.A. Psiholog icheskaya bezopasnost kak uslovie razvitiya lichnostnogo potentsiala [Psychological security as a condition of development of personal potential]. Vestnik TGU - Tomsk State University Bulletin. 2010; 338: 156-159 (in Russian).

5. Vasilyuk F.E. Psihologiya perezhivaniya [Psychology of experince]. M., 1984 (in Russian).
6. Gutkevich E.V. Sovremennaya semya v aspekte psihologii zdorovya lichnosti: problemyi razvitiya i vozmozhnosti preventsii [Modern family in aspect of psychology of health of the personality: problems of development and possibilities of prevention]. Sibirskiy psihologicheskiy zhurnal - Siberian Psychological Journal. 2014; 51: 120-132 (in Russian)

7. Drozhdina E.N., Kovalevskaya O.B., Seravina O.F. i dr. Rol psihotravmiruyuschih faktorov $\mathrm{v}$ dezadaptatsii detey i podrostkov, stradayuschim yuvenilnyim artritom [Role of psychotraumatizing factors in disadaptation of children and adolescents suffering from juvenile arthritis]. Sotsialnaya i klinicheskaya psihiatriya - Social and Clinical Psychiatry. 2012; 22 (1): 44-46 (in Russian).

8. Igumnov S.A. Psihicheskoe razvitie detey $\mathrm{v}$ norme $\mathrm{i}$ patologii [Mental development of children in norm and pathology]. SPb.: Piter, 2004: 480 (in Russian).

9. Kulakov S.A. Osnovyi psihosomatiki [Bases of psychosomatics]. SPb.: Rech, 2003: 287 (in Russian).

10. Kuftyak E.V. Sovladanie i psihologicheskie zaschityi suprugov v period dinamicheskih krizisov: Semeynaya ustoychivost kak psihologicheskiy fenomen [Coping and psychological defenses of spuses in the period of dynamic crises: family resistance as a psychological phenomenon]. Meditsinskaya psihologiya v Rossii Medical Psychology in Russia. 2014; 1 (24): 11 URL: http://mprj.ru (in Russian).

11. Leontyev D.A., Mandrikova E.Yu., Osin E.N., Plotnikova A.V., Rasskazova E.I. Opyit strukturnoy diagnostiki lichnostnogo po- 
tentsiala. Psihologicheskaya diagnostika [Experience of structural diagnostics of the personal potential. Psychological diagnostics]. M., Obninsk, 2007; 1: 8-31 (in Russian).

12. Lifintseva A.A., Holmogorova A.B. Semeynyie faktoryi psihosomaticheskih rasstroystv u detey i podrostkov [Family factors of psychosomatic disorders in children and adolescents]. Konsultativnaya psihologiya i psihoterapiya - Counseling Psychology and Psychotherapy. 2015; 23 (1): 70-83 (in Russian).

13. Mazurova N.V. Semya i bolezn rebYonka: voprosyi psihologicheskoy adaptatsii. Lichnost, semya i obschestvo: voprosyi pedagogiki i psihologii: materialyi XXXI mezhdunarodnoy zaochnoy nauchno-prakticheskoy konferentsii [Family and illness of the child: issues of psychological adaptation. Personality, family and society: questions of education and psychology: materials of the XXXIst International Online Theoretic and Practical Conference]. Novosibirsk, 2013: 110-120 (in Russian).

14. Merinov A.V., Somkina O.Yu. Vliyanie razvoda na suitsidologicheskie i lichnostno-psihologicheskie harakteristiki muzhchin, stradayuschih alkogolnoy zavisimostyu [Influence of divorce on suicidological and personality-psychological characteristics of men suffering from alcohol dependence]. Meditsinskaya psihologiya v Rossii - . Medical Psychology in Russia 2013; 2 (19) (in Russian).

15. Nikolskaya I.M. Klinicheskaya psihologiya semi: osnovnyie polozheniya [Clinical psychology of a family; basic propositions]. Meditsinskaya psihologiya v Rossii - Medical Psychology in Russia. 2010; 4 URL: http://medpsy.ru (in Russian).

16. Nikolskaya I.M. Psihologicheskaya zaschita i koping-povedenie v ekstremalnyih i chrezvyichaynyih situatsiyah. Okazanie psihologicheskoy i psihiatricheskoy pomoschi pri chrezvyichaynyih situatsiyah: uchebnoe Posobie [Psychological defense and copingbehavior in emergency situations. . Psychological and psychiatric aid rendering in emergency situations: tutorial]. A.M. Chakiev, ed. Bishkek, 2013: 33-40 (in Russian).
17. Novikova E.V. O nekotoryih harakteristikah obscheniya mezhdu suprugami [About some characteristics of communication between spouses]. Voprosyi psihologii - Issues of Psychology. 2009; 4: 1519 (in Russian).

18. Olifirovich N.I.., Zinkevich-Kuzemkina T.A, Velenta T.F. Psihologiya semeynyih krizisov [Psychology of Family crises]. SPb.: Rech, 2006: 360 (in Russian).

19. Holmogorova A.B., Volikova S.V. Semeynyiy kontekst rasstroystv affektivnogo spectra [Family context of affective spectrum disorders]. Sotsialnaya i klinicheskaya psihiatriya - Social and Clinical Psychiatry. 2004; 2: 11-20 (in Russian).

20. Holmogorova A.B., Garanyan N.G., Shayb P., Virshing M. Emotsii i psihicheskoe zdorove $\mathrm{v}$ sotsialnom i semeynom kontekste (na modeli somatoformnyih rasstroystv) [Emotions and mental health in social and family context (somatoform disorders' modelbased)]. Meditsinskaya psihologiya v Rossii - Medical Psychology in Russia. 2011; 1. URL: http:// medpsy.ru (in Russian).

21. Eydemiller E.G., Nikolskaya I.M., Dobryakov I.V. Semeynaya psihoterapiya i klinicheskaya psihologiya semi: traditsii i sovremennoe sostoyanie [Family psychotherapy and clinical psychology of family: traditions and modern state]. Meditsinskaya psihologiya v Rossii - Medical Psychology in Russia. 2014; 6 (29). URL: http://mprj.ru (in Russian).

22. Duggan C., Sham P., Burleson, M.H., Trevathan, W.R., \& Todd M. P. Family history as a predictor of poor long - term outcome in depression. British Journal of Psychiatry. 2000; 157: 185191.

23. Lecic-Tosevski D., Vukovic O., Stepanovic J. Stress and personality. Psychiatrike. 2011; Oct.-Dec; 22 (4): 290-297.

Received April 20.2017

Accepted June 26.2017

Kostarev Vladislav V., lecturer of Psychology and Speech Therapy Department, Branch of Moscow Psychological-Social University, Krasnoyarsk, Russian Federation

Kostarev Vladislav V., vladkost@list.ru 